\title{
大阪湾湾奥部における青潮の再現計算 \\ Numerical Simulation of Blue Tides in the Head of Osaka Bay
}

\author{
金澤 剛 $^{1} \cdot$ 藤原隆一 ${ }^{2} \cdot$ 鯉㴊幸生 $^{3} \cdot$ 磯部雅彦 $^{4}$ \\ Tsuyoshi KANAZAWA, Ryuichi FUJIWARA, Yukio KOIBUCHI and Masahiko ISOBE
}

\begin{abstract}
Blue tide events were observed four times in the head of Osaka Bay from July to September, 2005. Strong north wind from the land blew continuously in each event, and the sudden fall of the water temperature of the surface layer and DO of the middle layer were observed at the same time. The upwelling of anoxic water was regarded as the dominant factor of the blue tide events. To discuss these processes, we carried out now cast simulation by using the threedimensional numerical model by focusing on DO. As a result, the blue tide events and the difference of scales among the events were reproduced. The difference was attributed not only to the strength and weakness of north wind but also to the duration and a condition of the thermal stratification.
\end{abstract}

\section{1. はじめに}

夏季の東京湾，特に湾奥部の北岸で発生する青潮は, 海域環境の悪化が目に見える形で現れることから，人々 が海域の環境状態を知る指標のひとつと言える。この東 京湾における青潮は, 底層に形成される貧酸素水塊の湧 昇に起因することは良く知られており，規模が大きな場 合には湾奥沿岸に存在する浚渫窪地が影響していること も指摘されている（佐々木ら，1996）。また，近年では 東京湾西岸でも青潮が確認されており, 鯉渕ら（2005） は現地観測と 3 次元数值モデルによるナウキャストシミ ユレーションによってその発生過程を検討している. こ のように, 東京湾の青潮については, その発生過程の究 明, 再現計算が行われており, 簡易的な予測手法も佐々 木ら（1999）によって提案されている.

一方，大阪湾の湾奥部においても，近年，青潮の発生 が確認されている（中过ら，2003; 藤原ら，2005）.こ の大阪湾湾奥部における青潮の発生機構について, 中辻 ら（2003）は, 通常, 夏季の大阪湾湾奥部では南西風が 卓越するのに対し, 北西風が連吹したときに底層水が湧 昇して青潮が発生したと述べている．藤原ら（2005）も 風速 $10 \mathrm{~m} / \mathrm{s}$ 程度の東北東からの風が連吹した間のみ発生 していたと報告している.ところで, 大阪湾を対象とし た数值計算に関しては, 入江ら（2004）が貧酸素水塊の 挙動に関して検討をおこなっているものの, 青潮の発生 過程の再現を意図したものはないようである。そこで本 研究では, 大阪湾湾奥部で発生した青潮の発生過程につ

\begin{tabular}{|c|c|c|}
\hline 1 正会員 & 工修 & 東洋建設 (株) 鳴尾研究所 \\
\hline 正会 & 博 (工) & 設 (株) 鳴尾研究所 \\
\hline 正会員 & 博 (工) & 大学講師 大学院新領域創成科学研 \\
\hline - & 工博 & $\begin{array}{l}\text { 東京大学教授 大 } \\
\text { 究科環境学専攻 }\end{array}$ \\
\hline
\end{tabular}

いて検討することを目的に現地観測を実施した（藤原， 2009)。そして，2005年に観測した青潮発生状況に基づ いて，特にDOに着目した 3 次元数值モデルによる 2005 年夏季の水質再現計算を実施し, 湾奥部での青潮の再現 を試みた。

\subsection{5 年夏季の青潮発生状況}

\section{（1）現地観測の概要}

大阪湾湾奥部における青潮の発生に関する現地調査 は, 2004年夏季より主として, 図-1に示す西宮市鳴尾浜 から甲子園浜にかけての海域を対象に海色に関する定点 観測を行った。さらに，2005年7月からは鳴尾浜地先に て水温とDOの連続観測を実施している. 観測地点は水 深がD.L.-5.5m, 潮位はH.W.L.がD.L.+1.65m, L.W.L.が D.L.+0.05mである. 計測器は図-2に示すように, 岸壁か ら吊り下げてシンカーで固定したロープに所定の高さで 取り付けた。計測高さは水温計（JFEアレック電子社製 MDS-MkV/T) がD.L.-1m，-3m，-5mの3 䇢所, DO 計 （JFEアレック電子社製COMPACT DOW）が海底上 $2.5 \mathrm{~m}$ にあたるD.L.-3mである。計測は測定時間間隔 10 分間で 連続観測した。

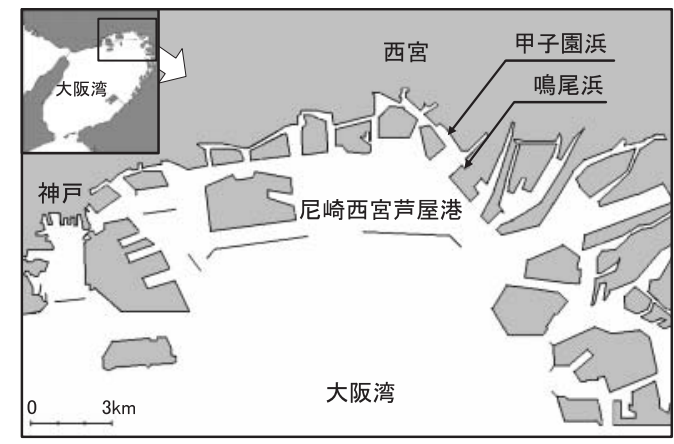

図-1 観測位置図 


\section{（2）青潮発生時の状況}

海色に関する定点観測の結果，大阪湾の最奥部に位置 するこの海域において，2005年には少なくとも4回の青 潮に特有な海色の変化を確認した（表-1）。狭い海域での み確認したものではあるが，1回目（7月25日〜26日） と 2 回目（8月 25 日）の青潮は比較的規模が小さく, 3 回 目（9月 5 日〜 6 日）と 4 回目（9月 24 日〜 25日)，特に 4 回目の青潮はやや規模の大きなものであった。図-3は， 4 回の青潮発生期間を含む 2005 年 7 月 21 日から 9 月 30 日 までの大阪管区気象台における風向風速と鳴尾浜地先で の水温㧤よびDOの観測結果の時系列である。図中，八 ッチをかけた期間が青潮の発生月日を表す。この期間の 風は，概ね夏季の卓越風である南西風が吹いているが, 青潮が発生した 4 回の期間は，いずれも強い北系の風の 連吹中であったことがわかる。

この北系の風が連吹した期間の天気図によれば，7月 25日～26日は台風第7号（T0507）が本州南方の海上を 北上後，房総半島に上陸，8月 25 日は台風第 11 号 （T0511）が本州南岸に接近，9月 5日～6日は台風第 14 号 （T0514）が九州の西の海上を北上し長崎県に上陸，9月 24日～25日は台風第17号（T0517）が伊豆諸島南部から 関東の東海上に進むといったように，いずれの期間も日 本の近海に台風が存在していた。したがって，これらは 台風の影響による北系の強風であったと推察される。

この 4 回の青潮発生期間の強風は，いずれも同程度の 風速があるにもかかわらず，1，2回目の青潮と $3 ， 4$ 回目 の青潮とで発生が確認された海域の規模が異なるのは, 7 月と 8 月に発生した 1,2 回目の青潮は成層が発達して いたために，風の力が下層まで伝わる割合が小さく，逆
に9月に発生した 3,4 回目の青潮は成層が弱いために, 風の力が下層まで伝わっていたものと考える.

\section{(3) 水温およびDOの観測結果}

図-3に示した水温の観測結果によれば，8月の終わり までは強い成層が形成されているのに対し，9月に入る と成層強度が徐々に弱まっていくのが特徵的である. また，北系の風の連吹が始まる度に，表層および中層 の水温が徐々に低下し成層が破壊されている。これは, 陸からの風である北系の風によって表層水が沖に移動 し，下層の水が表層まで到達したことを意味しており， 貧酸素の底層水が湧昇して青潮が発生したとする考え と一致する。

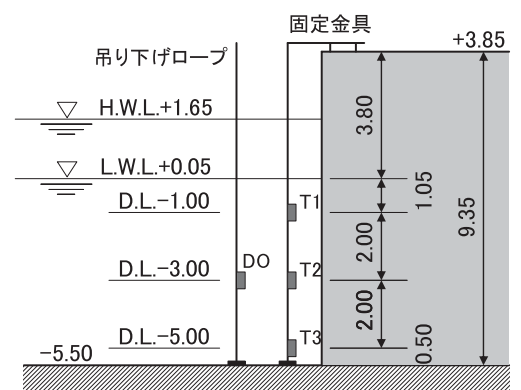

図-2＼cjkstart計測器の設置状況（水温計：T，DO計：DO)

表-1＼cjkstart青潮の発生月日（2005年）

\begin{tabular}{l|l|c}
\hline & \multicolumn{1}{|c|}{ 発生月日 } & 海 域 \\
\hline 1 & $7 / 25-7 / 26$ & 鳴尾浜 \\
\hline 2 & $8 / 25$ & 鳴尾浜 \\
\hline 3 & $9 / 5-9 / 6$ & 鳴尾浜・甲子園浜 \\
\hline 4 & $9 / 24-9 / 25$ & 西宮から甲子園浜 \\
\hline
\end{tabular}
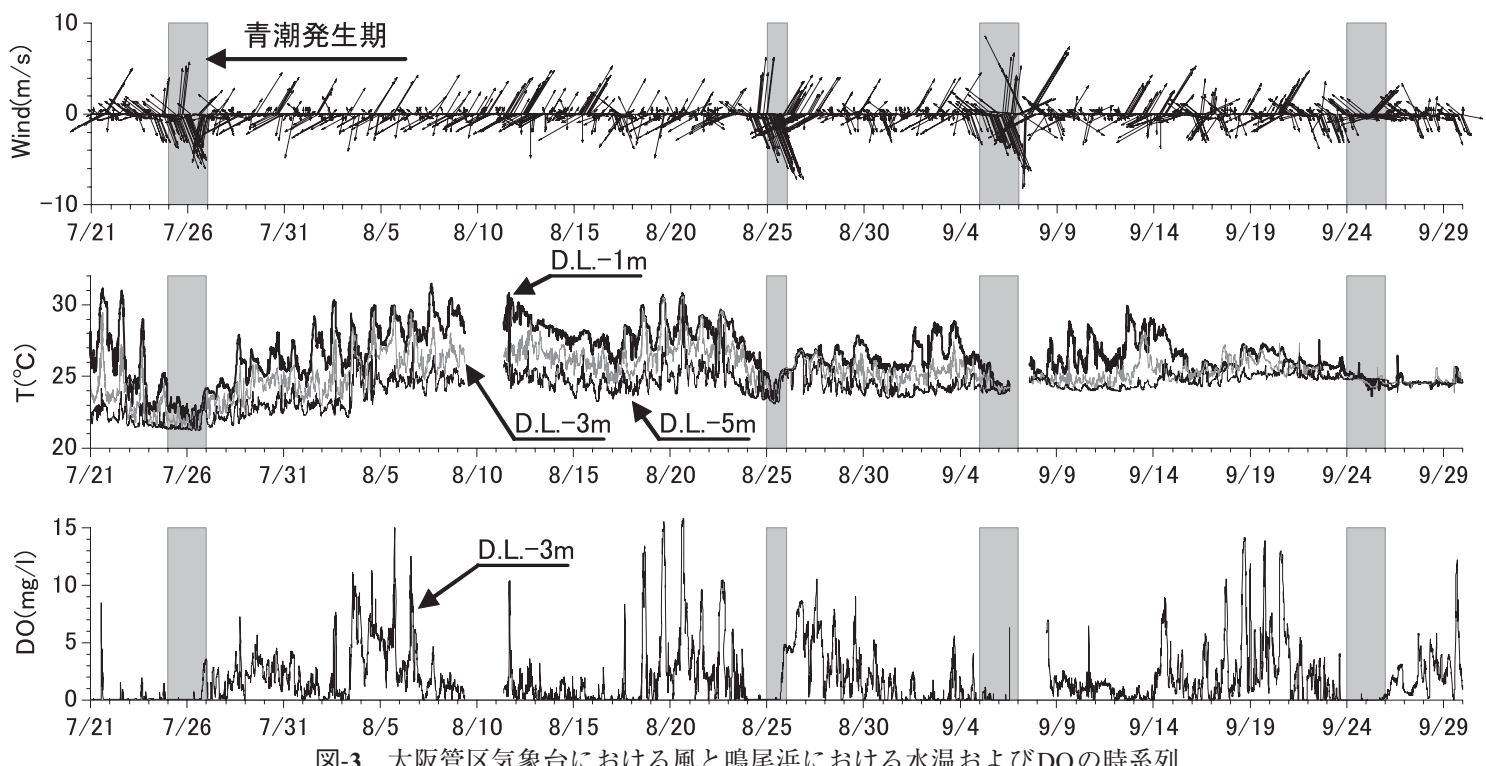

図-3 大阪管区気象台における風と鳴尾浜における水温抒よびDOの時系列 
DOの観測結果によれば，この期間，比較的DOが高い 状態と低酸素な状態が繰り返し出現しており, このDO 計の設置高さ (D.L.-3m) 付近に, 底層の貧酸素水塊の 境界面があるものと考えられる.1点の観測結果ではあ るが，青潮発生前には比較的DOが高いのが，青潮発生 期間では貧酸素となり, 青潮発生後の風向きの急変にと もない認められるDOの回復が青潮の収束と一致してい ることから, DOの観測結果からも貧酸素水塊の湧昇が あったことが推察される.

これらから，この大阪湾湾奥部での青潮の発生原因は, 中辻ら（2003）や藤原ら（2005）が示したように, 北系 の離岸風の連吹によって表層水が沖合いに移動し, 貧酸 素の底層水が湧昇したためと考えられる.

\section{3 次元数值モデルの概要}

\section{（1）流動モデル}

流動・密度場の計算には, 静水圧近似とブシネスク近 似を仮定したNavier-Stokesの式，連続式，水温・塩分の 移流拡散方程式および密度の状態方程式を基礎方程式と する鯉㴊ら（2001）の $\sigma$ 座標系による3 次元流動モデル を用いた。

\section{（2）生態系モデル}

大阪湾が十分に富栄養化した海域であるとして，青潮 のもととなる貧酸素水塊の挙動を検討するため, 鯉㴊ら （2001）の水質モデルを簡略化し, 植物プランクトン $\left(C_{\mathrm{PPL}}\right)$ ，デトリタス $\left(C_{\mathrm{DET}}\right)$ および $\mathrm{DO}\left(C_{\mathrm{DO}}\right)$ からなる 簡易な 3 次元生態系モデルを適用した. 各変数の生成項 を以下に示す。

$$
\begin{aligned}
& \frac{\partial C_{\mathrm{PPL}}}{\partial t}=(\text { 光合成による増殖 }) \\
& \text { - (枯死 })-(\text { 呼吸 })-(\text { 沈降 }) \\
& \frac{\partial C_{\mathrm{DET}}}{\partial t}=(\text { 植物プランクトンの死骸 }) \\
& \text { - (バクテリアによる分解 })- \text { (沈降) } \\
& \frac{\partial C_{\mathrm{DO}}}{\partial t}=(\text { 光合成による生産 }) \\
& \text { - (有機物の分解による消費) } \\
& \text { - (植物プランクトンの呼吸による消費) } \\
& + \text { (海面でのばっ気 })-(\text { 底泥での消費 }) \cdots(
\end{aligned}
$$

すなわち，DOは植物プランクトンの光合成による生 産と海面でのばっ気によって増加し, 植物プランクトン の呼吸と有機物の分解および底泥での消費によって減少 するとした。

植物プランクトンの成長速度 $G$ は, 最大成長速度に強 光阻害を考慮したSteeleの光合成速度を乗じた次式とし た（Kremer \& Nixon, 1973）.

$$
G=G_{\max } \cdot \frac{I}{I_{\mathrm{opt}}} \exp \left(1-\frac{I}{I_{\mathrm{opt}}}\right)
$$

ここに, $G_{\max }, I, I_{\mathrm{opt}}$ はそれぞれ植物プランクトンの 最大成長速度, 光の強度, 光の最適強度である. $G_{\max }$ は 水温 $T$ の指数関数で表される次式を採用した（Kremer \& Nixon, 1973).

$$
G_{\max }=\frac{0.59}{24 / 3600} \exp 0.0633 T
$$

深さ $z$ における光の強度はLambert-Beerの法則に従う ものとした.

$$
I=I_{0} \exp (-k z)
$$

ここに $I_{0}$ は水面での光強度, $k$ は消散係数でKremer \& Nixon（1973）にならい次式とした.

$$
k=0.04+0.054 C_{\mathrm{PPL}}^{2 / 3}+0.0088 C_{\mathrm{PPL}}
$$

植物プランクトンの呼吸による自己分解 $R_{\mathrm{PPL}}$ は, 松梨 （1993）にならい水温の関数で与えた.

$$
R_{\mathrm{PPL}}=R_{\mathrm{PPL} 20} \theta^{T-20}
$$

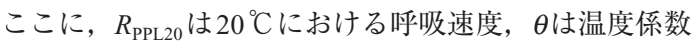
である．植物プランクトンの枯死は枯死速度 $m_{\mathrm{PPL}}$ により 現存量に比例する形で表し, デトリタスの分解 $R_{\mathrm{DET}}$ は水 温・DO依存性を持つ分解速度を次式で与えた（佐々木 ら, 1998).

$$
R_{\mathrm{DET}}=5.8 \times 10^{-6} \exp 0.007 T \frac{C_{\mathrm{DO}}}{K_{\mathrm{DO}}+C_{\mathrm{DO}}} \cdots \cdots \cdots(9)
$$

ここに， $K_{\mathrm{DO}}$ は半飽和定数である.

水面におけるばっ気は再ばっ気係数 $K_{\mathrm{a}}$ を用いて飽和 DO 濃度からの不足分に比例したフラックスがあるとし た. 底泥での酸素消費は酸素消費速度 $W_{\mathrm{DO}}$ を水温の関数 で与えた。表-2に計算に用いた各パラメータを示す。

\section{(3) 計算条件}

計算は図-4に示す和歌山市以北，兵庫県高砂市以東の $63 \mathrm{~km}$ 四方の大阪湾であり, 水平方向は $1 \mathrm{~km}$, 鉛直方向は

表-2 水質モデルパラメータ

\begin{tabular}{c|c}
\hline$I_{\mathrm{opt}}\left(\mathrm{cal} / \mathrm{cm}^{2} /\right.$ day $)$ & 200 \\
\hline$R_{\mathrm{PPL} 20}(1 /$ day $)$ & 0.1 \\
\hline$\theta$ & 1.07 \\
\hline$m_{\mathrm{PPL}}(1 /$ day $)$ & 0.1 \\
\hline$K_{\mathrm{DO}}\left(\mathrm{g} / \mathrm{m}^{3}\right)$ & 0.5 \\
\hline$K_{\mathrm{a}}(1 / \mathrm{day})$ & 0.02 \\
\hline$W_{\mathrm{DO}}\left(\mathrm{g} / \mathrm{m}^{2} /\right.$ day $)$ & $5.0^{*} 1.07^{T-20}$ \\
\hline
\end{tabular}


20 層で分割した．計算の開始は4月1日として，11月末 までの8ケ月間にわたってナウキャストシミュレーショ ンを実施した。境界条件には和歌山および高砂の開境界 で，それぞれ，和歌山験潮所（気象庁）および兵庫県高 砂潮位観測所（兵庫県県土整備部）の1時間ごとの潮位 記録と兵庫県水産技術センター（2007）による毎月の水 温および塩分の観測結果から鉛直分布を与えた。また， 気象デー夕は大阪管区気象台（気象庁）の毎時の観測結 果を与えた。さらに，河川流量は淀川および大和川の毎 時の観測結果（国土交通省）を与え,淀川，大和川以外の 主要河川は神崎川, 武庫川, 新湊川, 大津川および男里 川の 5 河川に集約して，それぞれの時間流量は大和川の 時間流量に平均流量比（国土交通省近畿地方整備局）を 乗じて設定した。

\section{4. 計算結果}

\section{（1）流動の再現性}

シミュレーションの実施に先立ち，本モデルの流動の 再現性について検討するため，大阪湾を対象とした夏季 の定常計算を実施した。潮位境界条件はM2 分潮とし, 境界水温㧍よび塩分，気象条件および河川流入量は収集 した 2005 年のデータから 7 月と 8 月の平均值を与えた. なお，風は無風状態とした。計算は50潮汐分行った。

図-5に水深 $4 \mathrm{~m}$ における残差流の水平分布を示す。大 阪湾でみられる代表的な残差流は，潮汐に関連する湾西 部の沖ノ瀬還流と湾東部の成層域の上層に形成される西 宮沖還流である。図-5によれば，それらの循環流が認め られ，また，等密度線の分布も既往の研究成果（例えば, 入江ら，2004）と似た傾向を示している。また，底層の 残差流分布では，淀川等の湾奥に位置する河川からの表 層流出を補償する湾奥向きの流れが再現されていた。こ うしたことから，本流動モデルは大阪湾の流動を十分再 現していると判断した。

\section{(2) 青潮の再現計算結果}

図-6は2005年 4 月から 11 月までの鳴尾浜付近での水温 の計算結果を，図-3に示した鳴尾浜に扔ける水温の観測結 果とともに示したものである．上段が表層水温，下段が底 層水温を表し，図中黒い実線が観測結果，灰色の実線が計 算結果である。なお，観測は 2005 年 7月 12 日に開始して いる．春先から計算を開始した水温は夏季の上昇とその後 の低下といった長期的なトレンドをよく再現している．短 期的な水温の変化に着目すると, 計算結果は観測結果に比 べてやや変化が鈍いが，青潮の発生に合わせて観測された 表層水温の低下が概ね再現されている。ただし，観測結果 と比較すると, 計算結果は表層水温と底層水温の差が小さ い傾向にある，すなわち，成層強度の再現性に幾分問題を 残しており, この改善が今後の課題である.

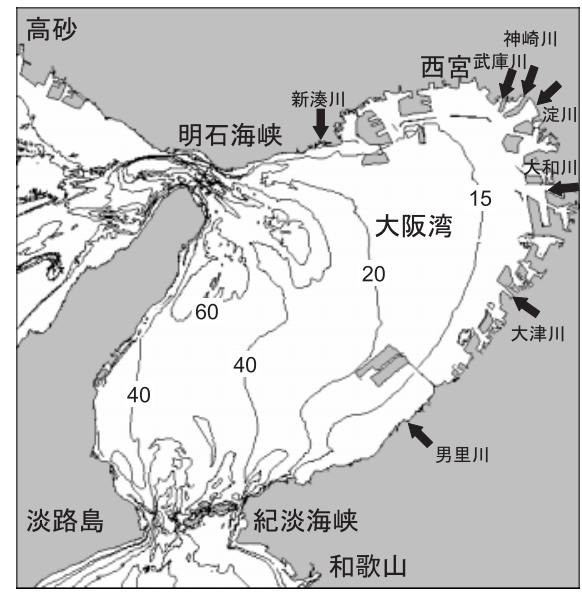

図-4 計算対象領域

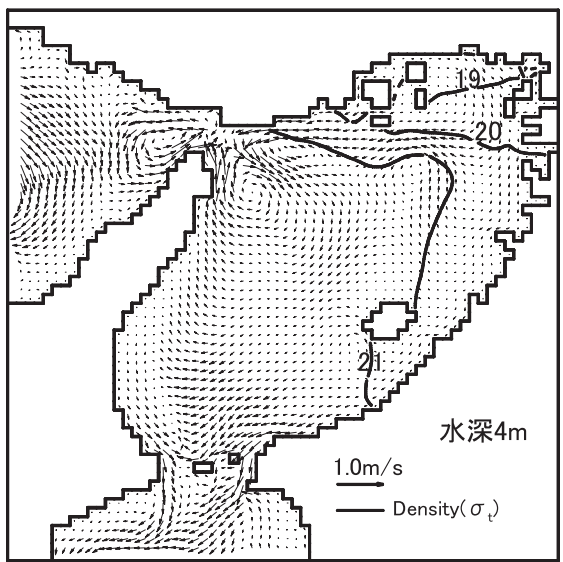

図-5 水深 $4 \mathrm{~m}$ における残差流の水平分布

図-7は鳴尾浜付近におけるDOの計算結果を鉛直分布 の時間変化として示したものである。青潮が観測された 4 回それぞれの期間に扔いて，表層に底層の貧酸素水塊 が到達している様子が確認できる。しかしながら低下し た表層のDO濃度は図-3に示した観測結果に比較すれば 高く，定量的な再現性には課題を残した。ただし，8月 の青潮発生前には底層 DOが極めて低濃度であるにもか かわらず，湧昇した底層水が比較的低酸素であったこと は，観測結果から成層が強かったために大規模な青潮に 至らなかった観測結果と対応する。一方，9月は貧酸素 状態の強い底層水が湧昇した様子が計算されており，成 層強度が弱い条件の下，比較的大規模に観測された青潮 に対応していると考えられ，本モデルは青潮発生時の貧 酸素水の挙動特性を概ね再現したと考える。

\section{5. まとめ}

本研究では，大阪湾を対象に青潮の発生過程について 検討することを目的に，2005年に大阪湾湾奥部で確認し 

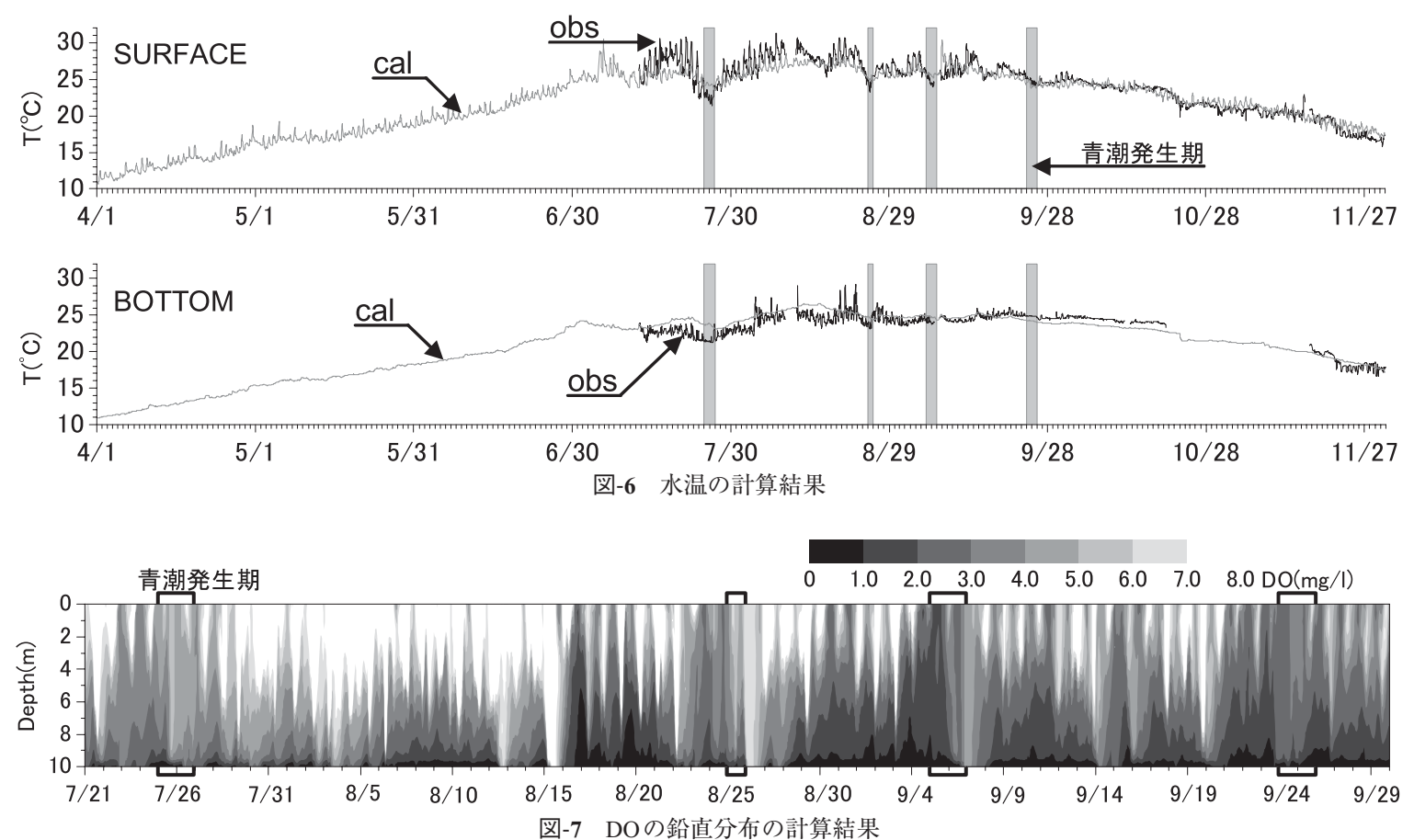

た青潮の再現計算を行った。その結果，（1）2005年に大 阪湾湾奥部で確認した4回の青潮では，その全ての期間 に北系の離岸風が連吹しており, 表層水温の急激な低下 とDOの低下が認められた。これは, 表層水の移動に伴 って筫酸素の底層水が湧昇したものと考えられ，これが 大阪湾湾奥部での青潮の発生機構であると考えられた. （2）数值計算により，これら 4 回の青潮発生期に, 貧酸 素の底層水が湧昇したことを再現した。この筫酸素水の 挙動は, 北系の風の強弱だけでなく, その連吹時間や成 層強度の条件によって変化した青潮の観測結果と概ね一 致した. しかしながら, 成層強度の再現性や湧昇した際 の表層DO濃度の定量的な再現性に今後の課題を残した。

\section{参 考 文 献}

入江政安・中辻啓二・西田修三 (2004)：大阪湾における貧酸 素水塊の挙動に関する数值シミュレーション, 海岸工学 論文集, 第 51 卷, pp. 926-930.

気象庁：潮汐観測資料, 和歌山（オンライン）, http://www.data.kishou.go.jp/kaiyou/db/tide/genbo/index.php, 参照 2007-06-28.

気象庁：過去の気象デー夕検索, 大阪 (オンライン), http://www.data.jma.go.jp/obd/stats/etrn/index.php, 参照 2007-06-28.

鯉㴊幸生・佐々木 淳・磯部雅彦（2001）：東京湾における窒 素・リンに着目した物質循環機構, 海岸工学論文集, 第 48卷, pp. 1076-1080.

鯉㴊幸生・磯部雅彦（2005）：2004年の東京湾西岸横浜港周辺 における青潮の発生要因, 海岸工学論文集, 第 52 巻, pp. 896-900.
国土交通省：水文水質データベース（オンライン）, http://www1.river.go.jp/, 参照 2007-11-08.

国土交通省近畿地方整備局：大阪湾環境データベース, 河川 流量 (オンライン), http://kouwan.pa.kkr.mlit.go.jp/kankyodb/data/b1_09kasen.html, 参照 2007-11-08.

佐々木 淳・磯部雅彦・渡辺 晃・五明美智雄（1996）：東京 湾に扮ける青潮の発生规模に関する考察, 海岸工学論文 集, 第43巻, pp. 1111-1115.

佐々木 淳・佐貫 宏・磯部雅彦（1998）：東京湾に扔ける富 栄養現象の再現計算, 海岸工学論文集, 第 45 卷, pp. 1036-1040.

佐々木 淳・磯部雅彦・藤本英樹（1999）：東京湾に打ける青 潮簡易予測手法の開発, 海岸工学論文集, 第 46 巻, pp. 1006-1010.

中辻啓二 · 入江政安・西田修三・湯浅楠勝（2003）：大阪湾湾 奥部閉鎖性海域に扔ける筫酸素水塊の現地調査, 水工学 論文集，第47卷，pp. 1285-1290.

兵庫県県土整備部：潮位月表, 高砂（オンライン）, http://hyogo-kouwan.info/jsp/ChouiMonthSelect006.html, 参 照 2007-10-02.

兵庫県水産技術センター（2007）：平成17年度兵庫県立農林水 産技術総合センター年報（水産編），135p.

藤原隆一.小竹康夫 ·上田悦子・知振佐苗 (2005)：大阪湾で 発生した青潮の現地調査, 海洋開発論文集, 第 21 巻, pp. 361-366.

藤原隆一 (2009)：連続観測記録を用いた大阪湾奥の光環境に 関する一考察, 海岸工学論文集, 第 56 巻, 印刷中.

松梨史郎 (1993) : 閉鎖性海域の窒素・リン・溶存酸素の予測 モデル，海岸工学論文集，第40巻，pp. 1076-1080.

Kremer, J. N. and S. W. Nixon, 中田喜三郎監訳（1987）：沿岸 生態系の解析 A Coastal Marine Ecosystem-Simulation and Analysis, 生物研究社, $227 \mathrm{p}$. 